\title{
Varietal resistance of $B t$ cotton against sucking complex under field conditions at upper Sindh-Pakistan
}

\author{
Zafar Hussain Shah ${ }^{1 *}$ and Hakim Ali Sahito ${ }^{1,2}$ \\ 1. Department of Zoology, Faculty of Natural Sciences, Shah Abdul Latif University, Khairpur, Sindh - Pakistan \\ 2. Date Palm Research Institute (DPRI), Shah Abdul Latif University, Khairpur, Sindh - Pakistan \\ *Corresponding author's email: lakyarializafar@yahoo.com \\ Citation \\ Zafar Hussain Shah and Hakim Ali Sahito. Varietal resistance of Bt cotton against sucking complex under field \\ conditions at upper Sindh-Pakistan. Pure and Applied Biology. Vol. 9, Issue 1, pp1242-1252. \\ http://dx.doi.org/10.19045/bspab.2020.90102
}

\begin{tabular}{llll}
\hline \hline Received: 11/10/2019 & Revised: 31/12/2019 & Accepted: 02/01/2020 & Online First: 10/01/2020 \\
\hline
\end{tabular}

\section{Abstract}

The research work was carried out during Kharif season, 2018 to investigate the varietal resistance of six Bt cotton varieties i.e., FH-Lalazar, SS-32, Bt-CRIS-508, CRIS-510, FH-142 and CRIS-533 against sucking pests, jassid, whitefly, thrips and mealybug under field conditions. The maximum resistivity against jassids was observed in SS-32 (1.98) per leaf followed by Bt-CRIS-508 (2.01), CRIS-533 (2.10), CRIS-510 (2.11), FH-142 (4.02) and FH-Lalazar (4.06).Against whitefly SS-32 gave maximum resistance (5.99) per leaf followed by CRIS-533 (6.00), CRIS-510 (8.55), Bt-CRIS-508 (8.93), FH-142 (9.12) and FH-Lalazar (11.04). Against thripsSS-32 variety showed maximum resistance (8.57) per leaf followed by CRIS-510 (8.81), CRIS-533 (8.87), Bt-CRIS-508 (9.50), FH-142 (10.27) and FH-Lalazar (15.31), while against mealybug Bt-CRIS-508 found resistive (0.42) followed byCRIS-510 (0.43), FH142 (1.49), SS-32 (1.88), CRIS-533 (1.98) and FH-Lalazar (2.02). The overall results showed that cotton variety SS32 gave better resistance against overall sucking pests (4.60) per leaf followed by CRIS-533 (4.74), and CRIS-510 (4.97), while varieties Bt-CRIS-508 and FH-142 showed moderate resistance against sucking pests (5.21) and (6.23), respectively however; variety FH-Lalazar had not shown enough resistance (8.11) against all the four mentioned sucking pests, so cotton variety FH-Lalazar was considered as most susceptible Bt variety and SS-32 variety was found to be most resistive variety against all the four sucking pests except mealybug. So it is suggested that the variety SS-32 should be cultivated as it is less attacked by sucking pests.

Keywords: Bt cotton; Sucking pests; Vitro conditions

\section{Introduction}

Cotton (Gossypium hirsutum L.) is a very important crop containing fiber and maintaining cash. In 2017 the growing area of cotton crop in Pakistan was 2.489million hectares and its production was 10.671 million bales [1]. It is commercial, historical, industrial and cultural crop, its silver fiber attracts world's interest. In Pakistan it earns a substantial foreign exchange of $68 \%$ by exporting raw cotton and $7.1 \%$ in agriculture value addition and about $1.6 \%$ to GDP [2]. It is attacked by various sucking and chewing insect pests but major sucking complex among them are jassid, Amrasca biguttula biguttula (Ishida) whitefly, Bemisia tabaci (Gennadius), thrips, Thrips tabaci (Linderman), mealybug, Phenacoccus solenopsis (Tinsley) and aphid, Aphis gossypii (Glover) which are cause of the most damage to the cotton crop. Cotton jassid is the notorious sucking insect pest of cotton [3, 4]. This pest mainly found on lower side of plant leaves, sucks sap from lower side portion of the leaves and injects the poisonous substance into the plant tissues. So, plant leaves become wrinkled and this is the symptom of jassid infestation [5]. Cotton whitefly also lives underside of cotton leaves, sucks the cell sap, 
causes $50 \%$ reduction of the production of the bolls [6], also it is vector of famous disease of cotton crop namely cotton leaf curl virus $(\mathrm{CLCuV})$ [7]. There are about 600 host plants of whitefly, which is menacing to agriculturebased countries [8]. Thrips are tiny insect pests which live lower side of cotton leaves and gave harm to plant by sucking sap of the cell, due to that, the leaves of the cotton plant become cupshaped and of silvery appearance [3]. Mealybug is a small soft-bodied pest, which found mostly on the stem and leaves of the plant and sucks the cell sap [9]. Its adult female is covered over by waxy powder due to this; its common name is mealybug [10]. Its hosts are different like harvests, vegetables, decorative plants and weeds [11], it gave 14\% loss to cotton yield, recently it become serious pest of cotton [12]. These sucking pests are playing major role in reducing cotton production throughout the Pakistan [13, 14]. Due to massive usage of pesticides, these pests got high resistance and the environment becomes polluted along with different health risks [15, $16]$.

From 1996 world-renowned that Bt cotton is the definitive solution to overcome the resistivity problems against chewing pests. An enormous resistivity has been adopted by chewing pests such as Helicoverpa armigera, Pectinophora gossypiella, Earias vittella and Earias insulana against Bt cotton under field and laboratory conditions [17]. Therefore, without using insecticides, varietal resistance tactic is of huge importance $[18,19,20]$ for developing the pest management strategy, it is main requirement to understand the effect of different morphological characters of plants for the host selection behavior. In Pakistan, the breeders have evolved a number of varieties by focusing their concentration to enhance the yield capacity. Plant pests and natural enemies can be positively or negatively affected by many plant characters $[21,22]$. In Pakistan the preceding efforts were taken to investigate the tactics to increase host plant resistance to insect pests in cotton; like those of $[15,20,23,24]$, etc, but still a lot remains yet to be completed to reach some specific outcomes. Keeping in view; the importance of resistant varieties the present studies were conducted to screen out 6 cotton genotypes. The natural resistances against these sucking complexes were also determined. Thus, the main object was to observe the population fluctuation for most resistant and susceptible $\mathrm{Bt}$ cotton varieties against sucking insect pests.

\section{Materials and methods}

The experimental trial was conducted during Kharif season, 2018 to investigate the resistivity of Bt cotton varieties against sucking complex i-e., jassid, whitefly, thrips and mealybug under field conditions. For this purpose the seeds of six different $\mathrm{Bt}$ cotton varieties i.e., $\mathrm{T}_{1}=$ FH-Lalazar, $\mathrm{T}_{2}=\mathrm{SS}-32, \mathrm{~T}_{3}=$ Bt-CRIS-508, $\mathrm{T}_{4}=\mathrm{CRIS}-510, \mathrm{~T}_{5}=\mathrm{FH}-142$ and $\mathrm{T}_{6}=$ CRIS-533 were sown on ridges in North to South direction in a Randomized Complete Block Design (RCBD) having a treatment size of $100 \mathrm{sq}$ feet, which were replicated 4 times and kept without using of insecticides. The space of 2 feet was maintained between treatments and replications by separating each plot, while 18" distance was maintained between the ridge to ridge and 9" to 12" distance between plant to plant. Thinning, weeding and other agronomical practices were manually done. Before sowing the cotton crop, the pre-weedicide Stomp (FMC Pvt. Ltd. Pakistan) was applied for controlling the weeds.

When the sucking insect pests had made their initial appearance sporadically, the crop was checked for the presence of the sucking insect pests on a weekly basis. Twenty plants of each cotton variety were chosen, randomly per treatment/plot for recording pest population. Three leaves, one each from the bottom, middle and top portions of cotton plants were kept under observation for insect pest population. The information was obtained by the average counts of the pest per leaf. The varietal resistance was observed during the season of the most insect pest activity.

\section{Statistical analysis}

The information on the individual population of each sucking complex species was displayed through a different examination of the mean 
values. The methods were isolated by observing the Least Significant Difference (LSD) test at $(\mathrm{P}<0.05)$ through Statistics $(8.1)$ computer software, student package, USA. The relationship framework between the overall and individual population dynamics of the sucking complex on various cotton cultivated varieties was analyzed.

\section{Results}

As the infestation of the pest is to be reciprocal of the insect pest susceptibility, so with an increase in pest population per leaf, the relative resistance of the variety was considered to decrease as reported by Aslam et al. [25].

\section{Resistance of Bt cotton varieties to jassid}

The population of jassid started from the month of July when plant bore 5-6 leaves after one month of cultivation of the cotton crop under field conditions which remained active up to the end of September or harvesting of the crop. All the six cotton varieties were cultivated on the same date and at the same location which was infested by the sucking complex vigorously. From which cotton jassid pest was observed with the overall maximum mean population (4.06) per leaf on FH-Lalazar under field conditions (Table 1). This variety had maximum number of jassids followed byFH142 (4.02), CRIS-510 (2.11), CRIS-533 (2.10) and Bt-CRIS-508 (2.01) per leaf throughout the cotton crop season but the least number of jassids were found on SS-32 (1.98) per leaf that found comparatively resistant when compared to the other tested varieties.

Further, the ANOVA showed a significant difference in two groups $(\mathrm{DF}=11,5 ; \mathrm{F}=75.93$; $\mathrm{P}=0.001$ ) against jassid population, one of them included FH-Lalazar and FH-142, while the second group included CRIS-533, CRIS510, Bt-CRIS-508, and SS-32, respectively.

\section{Resistance of Bt cotton varieties to whitefly}

The population of whitefly on all the six $\mathrm{Bt}$ varieties of cotton was observed and It was found thatSS-32 variety was relatively more resistant to whiteflies among the tested varieties, as it is shown in (Table 2) per leaf least number of whiteflies (5.99) followed by CRIS-533 (6.00) whiteflies. The FH-Lalazar was found to be the most vulnerable as it showed maximum whiteflies per leaf (11.04), followed by FH-142, Bt-CRIS-508 and CRIS510 having (9.12), (8.93) and (8.55) whiteflies respectively. Overall results showed that FHLalazar was significantly different $(\mathrm{DF}=11,5$; $\mathrm{F}=13.24 ; \mathrm{P}=0.001$ ) from all other varieties containing the maximum number of whiteflies while Bt-CRIS-508, CRIS-510, FH-142 were statistically similar and CRIS-533, SS-32 were also similar to each other for whiteflies per leaf. Resistance of Bt cotton varieties to thrips The population of thrips was also observed on all the six tested varieties of cotton, the results revealed that SS-32 showed maximum resistance to thrips comparatively to other tested varieties (Table 3). It showed least number of thrips (8.57) per leaf followed by CRIS-510 (8.81), CRIS-533 (8.87). Similarly; the maximum number of thrips was found on FH-Lalazar (15.31) per leaf followed by FH142 (10.27) and Bt-CRIS-508 (9.50). All the varieties were significantly different $(\mathrm{DF}=11$, $5 ; \mathrm{F}=76.97 ; \mathrm{P}=0.001$ ) from one another except CRIS-510 and CRIS-533 which were nonsignificant to each other.

\section{Resistance of Bt cotton varieties to mealybug}

The population of mealybug appeared late in the $2^{\text {nd }}$ week of August on all the six tested varieties of the cotton crop as shown in (Table 4), among these varieties Bt-CRIS-508 and CRIS-510 showed maximum resistance to mealybug (0.42), (0.43) respectively as compared to other tested varieties. While all the other four varieties FH-142, SS-32, CRIS-533, and FH-Lalazar were containing almost similar mean population of mealybug (1.49), (1.88), (1.98) and (2.02) respectively. Among all these tested varieties FH-Lalazar was found less resistive to mealybug as compared with other varieties. The ANOVA showed the significant difference $(\mathrm{DF}=11,5 ; \mathrm{F}=5.97 ; \mathrm{P}=0.001)$ among all tested $\mathrm{Bt}$ varieties. 
Table1. Overall mean population of cotton jassid under field conditions during 2018

\begin{tabular}{|c|c|c|c|c|c|c|c|c|c|c|c|c|c|}
\hline Months & \multicolumn{4}{|c|}{ July } & \multicolumn{4}{|c|}{ August } & \multicolumn{4}{|c|}{ September } & \multirow{2}{*}{ Mean \pm S.E } \\
\hline Name of VarietylWeeks & $1^{\text {st }}$ & $2^{\text {nd }}$ & $3^{\text {rd }}$ & $4^{\text {th }}$ & $5^{\text {th }}$ & $6^{\text {th }}$ & $7^{\text {th }}$ & $8^{\text {th }}$ & $9^{\text {th }}$ & $10^{\text {th }}$ & $11^{\text {th }}$ & $12^{\text {th }}$ & \\
\hline FH Lalazar & 1.83 & 2.53 & 3.53 & 4.33 & 5.06 & 5.40 & 6.20 & 5.26 & 4.86 & 3.66 & 3.13 & 2.93 & $4.06 \pm 0.38^{\mathrm{a}}$ \\
\hline SS-32 & 0.46 & 1.80 & 1.96 & 2.06 & 2.13 & 2.26 & 3.13 & 2.26 & 2.06 & 2.00 & 1.93 & 1.73 & $1.98 \pm 0.17^{\mathrm{b}}$ \\
\hline Bt-CRIS-508 & 0.53 & 1.73 & 1.83 & 2.20 & 2.46 & 2.60 & 2.73 & 2.13 & 2.13 & 2.00 & 1.96 & 1.83 & $2.01 \pm 0.16^{\mathrm{b}}$ \\
\hline CRIS-510 & 0.56 & 1.93 & 2.03 & 2.26 & 2.33 & 2.40 & 3.00 & 2.46 & 2.33 & 2.10 & 2.02 & 1.86 & $2.11 \pm 0.17^{b}$ \\
\hline FH-142 & 1.8 & 3.54 & 3.40 & 3.86 & 4.06 & 4.20 & 5.60 & 5.13 & 5.20 & 4.16 & 4.06 & 3.20 & $4.02 \pm 0.29^{\mathrm{a}}$ \\
\hline CRIS-533 & 0.53 & 1.86 & 2.06 & 2.13 & 2.36 & 2.66 & 3.00 & 2.38 & 2.20 & 2.13 & 2.03 & 1.80 & $2.10 \pm 0.17^{b}$ \\
\hline
\end{tabular}

Means followed by common letters in the respective category are not significantly different from each other by LSD at $\alpha=0.05$

Table 2. Overall mean population of cotton whitefly under field conditions during 2018

\begin{tabular}{|c|c|c|c|c|c|c|c|c|c|c|c|c|c|}
\hline Months & \multicolumn{4}{|c|}{ July } & \multicolumn{4}{|c|}{ August } & \multicolumn{4}{|c|}{ September } & \multirow[b]{2}{*}{ Mean \pm S.E } \\
\hline $\begin{array}{c}\text { Name of } \\
\text { VarietylWeeks }\end{array}$ & $1^{\text {st }}$ & $2^{\text {nd }}$ & $3^{\text {rd }}$ & $4^{\text {th }}$ & $5^{\text {th }}$ & $6^{\text {th }}$ & $7^{\text {th }}$ & $8^{\text {th }}$ & $9^{\text {th }}$ & $10^{\text {th }}$ & $11^{\text {th }}$ & $12^{\text {th }}$ & \\
\hline FH Lalazar & 3.53 & 5.73 & 7.93 & 8.66 & 10.40 & 13.26 & 14.53 & 16.20 & 15.06 & 14.50 & 12.60 & 10.12 & $11.04 \pm 1.15^{\mathrm{a}}$ \\
\hline SS-32 & 0.46 & 1.26 & 3.80 & 4.46 & 4.86 & 5.86 & 6.00 & 8.40 & 11.60 & 8.60 & 8.40 & 8.20 & $5.99 \pm 0.94^{\mathrm{c}}$ \\
\hline Bt-CRIS-508 & 1.60 & 3.46 & 7.06 & 7.06 & 6.26 & 7.00 & 7.26 & 7.40 & 14.06 & 18.66 & 14.73 & 12.56 & $8.93 \pm 1.44^{\mathrm{b}}$ \\
\hline CRIS-510 & 1.66 & 3.66 & 5.00 & 5.26 & 5.86 & 6.66 & 6.73 & 12.53 & 13.26 & 15.00 & 14.53 & 12.40 & $8.55 \pm 1.35^{\mathrm{b}}$ \\
\hline FH-142 & 1.58 & 3.46 & 3.80 & 4.73 & 6.36 & 8.80 & 9.26 & 11.26 & 13.26 & 15.66 & 16.66 & 14.60 & $9.12 \pm 1.50^{\mathrm{b}}$ \\
\hline CRIS-533 & 0.93 & 2.73 & 2.93 & 3.06 & 4.13 & 5.13 & 6.53 & 7.00 & 7.60 & 8.33 & 12.93 & 10.70 & $6.00 \pm 1.02^{\mathrm{c}}$ \\
\hline
\end{tabular}

Means followed by common letters in the respective category are not significantly different from each other by LSD at $\alpha=0.05$ 
Table 3. Overall mean population of cotton thrips under field conditions during 2018

\begin{tabular}{|c|c|c|c|c|c|c|c|c|c|c|c|c|c|}
\hline Months & \multicolumn{4}{|c|}{ July } & \multicolumn{4}{|c|}{ August } & \multicolumn{4}{|c|}{ September } & \multirow[b]{2}{*}{ Mean \pm S.E } \\
\hline $\begin{array}{c}\text { Name of } \\
\text { Variety } \backslash \text { Weeks }\end{array}$ & $1^{\text {st }}$ & $2^{\text {nd }}$ & $3^{\text {rd }}$ & $4^{\text {th }}$ & $5^{\text {th }}$ & $6^{\text {th }}$ & $7^{\text {th }}$ & $8^{\text {th }}$ & $9^{\text {th }}$ & $10^{\text {th }}$ & $11^{\text {th }}$ & $12^{\text {th }}$ & \\
\hline FH Lalazar & 5.50 & 6.40 & 9.33 & 12.33 & 15.93 & 17.40 & 19.86 & 21.06 & 24.00 & 19.00 & 17.46 & 15.40 & $15.31 \pm 1.68^{\mathrm{a}}$ \\
\hline SS-32 & 2.76 & 2.86 & 3.40 & 5.26 & 7.33 & 9.06 & 12.86 & 13.33 & 14.53 & 12.00 & 10.80 & 8.60 & $8.57 \pm 1.23^{\mathrm{d}}$ \\
\hline Bt-CRIS-508 & 1.30 & 2.26 & 3.46 & 6.13 & 8.06 & 9.26 & 11.40 & 14.26 & 17.13 & 16.00 & 13.53 & 11.20 & $9.50 \pm 1.55^{b c}$ \\
\hline CRIS-510 & 0.54 & 1.20 & 2.26 & 4.26 & 7.53 & 10.93 & 11.46 & 13.93 & 16.66 & 15.00 & 12.00 & 10.00 & $8.81 \pm 1.61^{\mathrm{cd}}$ \\
\hline FH-142 & 2.24 & 3.20 & 5.26 & 7.20 & 10.26 & 11.80 & 13.80 & 15.93 & 16.60 & 14.33 & 12.26 & 10.39 & $10.27 \pm 1.39^{b}$ \\
\hline CRIS-533 & 0.46 & 1.26 & 2.40 & 4.13 & 7.73 & 10.80 & 13.06 & 15.26 & 16.00 & 15.33 & 11.00 & 9.00 & $8.87 \pm 1.64^{\mathrm{cd}}$ \\
\hline
\end{tabular}

Means followed by common letters in the respective category are not significantly different from each other by LSD at $\alpha=0.05$

Table 4. Overall mean population of cotton mealybug under field conditions during 2018

\begin{tabular}{|c|c|c|c|c|c|c|c|c|c|c|c|c|c|}
\hline Months & \multicolumn{4}{|c|}{ July } & \multicolumn{4}{|c|}{ August } & \multicolumn{4}{|c|}{ September } & \multirow{2}{*}{ Mean \pm S.E } \\
\hline Name of VarietylWeeks & $\mathbf{1}^{\mathrm{st}}$ & $2^{\text {nd }}$ & $3^{\text {rd }}$ & $4^{\text {th }}$ & $5^{\text {th }}$ & $6^{\text {th }}$ & $7^{\text {th }}$ & $8^{\text {th }}$ & $9^{\text {th }}$ & $10^{\text {th }}$ & $11^{\text {th }}$ & $12^{\text {th }}$ & \\
\hline FH Lalazar & 0.00 & 0.00 & 0.00 & 0.00 & 0.00 & 0.54 & 0.93 & 1.33 & 2.80 & 4.00 & 6.00 & 8.64 & $2.02 \pm 0.82^{\mathrm{a}}$ \\
\hline SS-32 & 0.00 & 0.00 & 0.00 & 0.00 & 0.00 & 0.66 & 0.96 & 1.46 & 2.40 & 3.33 & 5.93 & 7.80 & $1.88 \pm 0.75^{\mathrm{a}}$ \\
\hline Bt-CRIS-508 & 0.00 & 0.00 & 0.00 & 0.00 & 0.00 & 0.00 & 0.26 & 0.53 & 0.80 & 0.93 & 1.13 & 1.40 & $0.42 \pm 0.15^{b}$ \\
\hline CRIS-510 & 0.00 & 0.00 & 0.00 & 0.00 & 0.00 & 0.00 & 0.33 & 0.54 & 0.76 & 0.96 & 1.20 & 1.38 & $0.43 \pm 0.15^{b}$ \\
\hline FH-142 & 0.00 & 0.00 & 0.00 & 0.00 & 0.00 & 0.33 & 0.86 & 1.17 & 2.73 & 3.05 & 4.15 & 5.60 & $1.49 \pm 0.56^{\mathrm{a}}$ \\
\hline CRIS-533 & 0.00 & 0.00 & 0.00 & 0.00 & 0.00 & 0.60 & 1.03 & 1.73 & 3.20 & 4.33 & 5.66 & 7.17 & $1.98 \pm 0.73^{\mathrm{a}}$ \\
\hline
\end{tabular}

Means followed by common letters in the respective category are not significantly different from each other by LSD at $\alpha=0.05$ 


\section{Resistance of Bt cotton varieties to overall sucking pests}

The resistance level of tested Bt cotton varieties against different sucking complex is shown in (Fig. 1). It was observed that cotton variety SS32 showed better resistance to overall sucking pests (4.60) mean population per leaf followed by CRIS-533 (4.74) and CRIS-510 (4.97), while varieties Bt-CRIS-508 and $\mathrm{FH}-142$ showed moderate resistance to all sucking pests (5.21) and (6.23) mean population per leaf respectively; however, variety FH-Lalazar had not shown enough resistance (8.11) against all the four mentioned sucking pests, so it was considered as most susceptible among the tested transgenic varieties.

Further, the ANOVA showed that against sucking pests all the varieties were significantly different $(\mathrm{DF}=11,5 ; \mathrm{F}=65.74 ; \mathrm{P}=$ 0.001 ) from one to another except SS-32 and CRIS-533 which were non-significant to each other.

Means followed by common letters in the respective category are not significantly different from each other by LSD at $\alpha=0.05$.

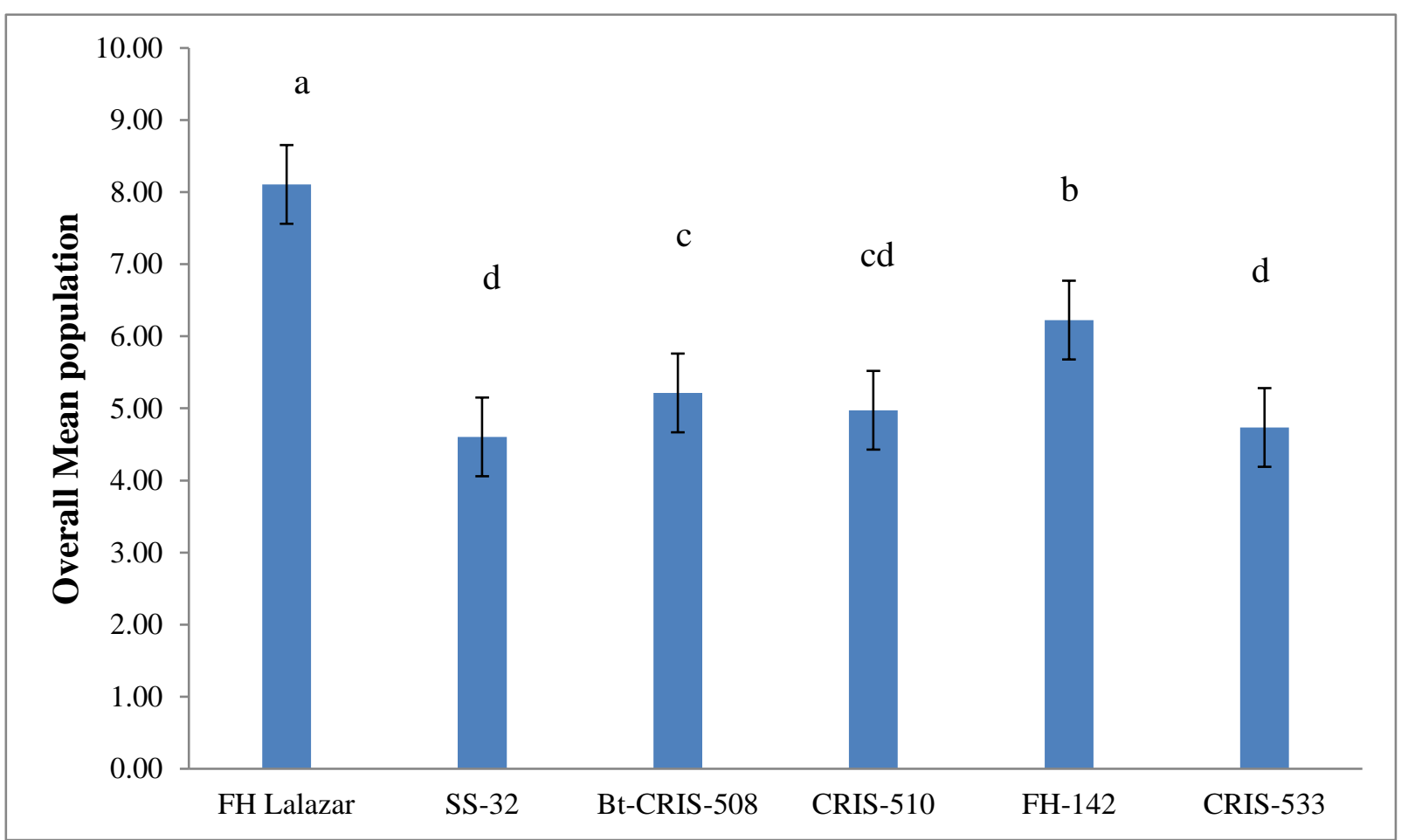

Figure 1. Overall mean population of sucking pests on different Bt varieties of cotton crop under field conditions

\section{Weekly population fluctuation of sucking complex}

The results of the population fluctuation of all the four sucking complex on various transgenic cotton varieties are shown in (Fig. 2) which illustrates that infestation of the jassid remained above economic threshold level (ETL) almost throughout experimental period except $1^{\text {st }}$ week of data collection and its peak population was found during $3^{\text {rd }}$ week of
August which is (3.94) per leaf. While the attack of whitefly remained below ETL in starting; during the first three weeks of July then gradually increased and crossed the ETL during the month of August and its population even more increased in September reached at peak (13.46) per leaf during $2^{\text {nd }}$ week of September. Likewise mean population of thrips on various $\mathrm{Bt}$ cotton varieties remained below ETL in July then its population crossed the ETL 
and reached at peak (17.49) per leaf in the last week of august then its population declined slowly but remained above ETL. As for as population fluctuation of mealybug is concerned on various Bt cotton varieties; it did not appear till the $1^{\text {st }}$ week of August on the all tested varieties of cotton crop, after appearance gradually its population increased day by day from the $2^{\text {nd }}$ week of August till the end of September.

Further, the ANOVA showed the overall significant difference $(\mathrm{DF}=5,11 ; \mathrm{F}=128.68$; $\mathrm{P}=0.001)$ against sucking pests among all the twelve weeks (throughout the season) from one to another except $9^{\text {th }}$ and $10^{\text {th }}$ week, which were non-significant to each other.

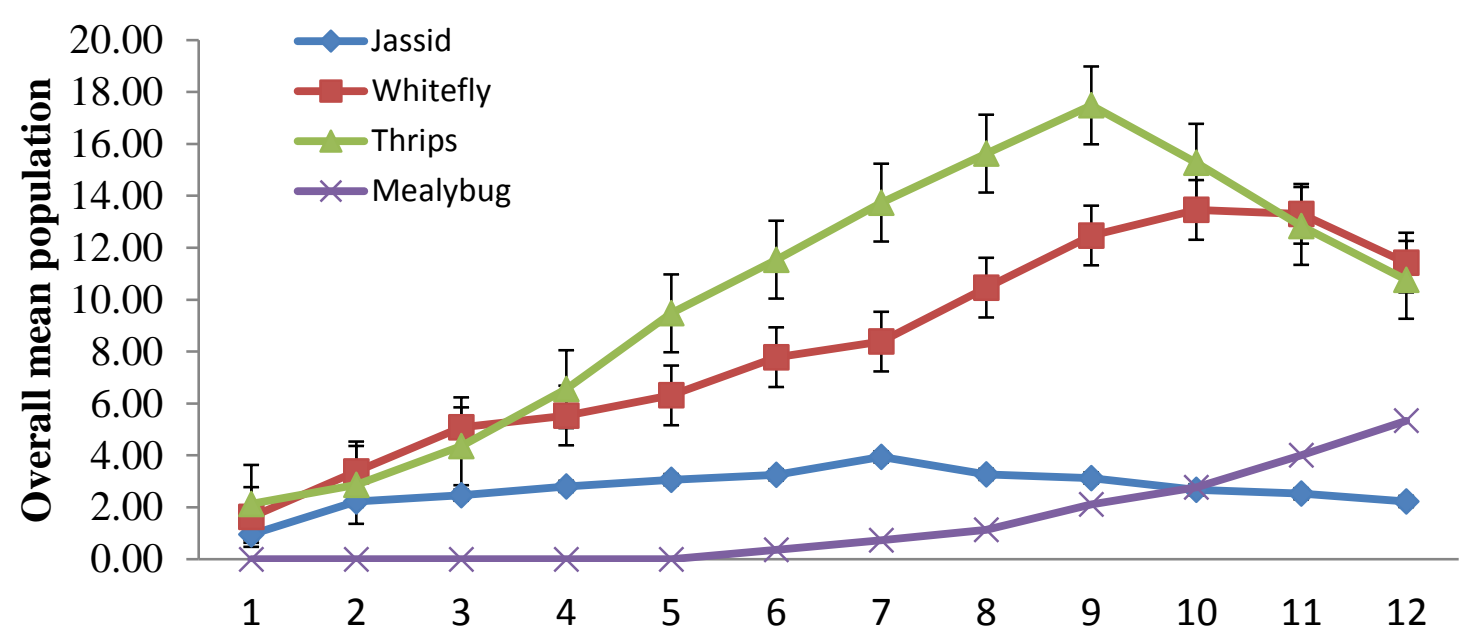

Figure 2. Weekly infestation ratio of sucking complex on Bt cotton varieties throughout the season

\section{Discussion}

In current research trial, six Bt cotton varieties were cultivated which were infested by the sucking complex vigorously, from which cotton jassid pest was observed with the overall per leaf maximum mean population (4.06) on FH-Lalazar under field conditions followed by FH-142 (4.02), CRIS-510 (2.11), CRIS-533 (2.10) and Bt-CRIS-508 (2.01) per leaf throughout the cotton crop season but the least number of jassids were found on SS-32 (1.98) per leaf that was found comparatively resistant to sucking pests when compared to other tested varieties. Our results are in similarity with [26, 27], they also found per leaf maximum population of jassid on two $\mathrm{Bt}$ varieties $\mathrm{FH}$ Lalazar and FH-142 as compare to other varieties. Further our results are in similarity with Saleem et al. [28] who also found maximum jassid population on FH-142 variety of Bt cotton. Sucking complex was found dangerous for the cotton crop, controlled by many methods among them varietal resistance of cotton is a major achievement in agriculture research. According to [29] the impact of cotton varieties on insect pests may be different and resistivity of cultivated varieties to insect pests could play a major role to obtained insect pests reduction biologically and cultivation varieties resistant to insect pests could play effective role to combat insect pests biologically. While population of whitefly on six Bt cotton varieties were observed among these varieties SS-32 variety was found relatively resistant to whiteflies, as it showed per leaf minimum number of whiteflies (5.99) 
followed by CRIS-533 (6.00), Whereas; FHLalazar was found to be the most vulnerable to whitefly as it showed maximum number of whiteflies per leaf (11.04), followed by $\mathrm{FH}-142$ (9.12), Bt-CRIS-508 (8.93) and CRIS-510 (8.55). Our results are in resemblance with [26] who found maximum whiteflies on $\mathrm{FH}$ Lalazar, and also in analogy with him on FH142 because he reported less number of whiteflies on FH-142, while in similarity with [27] who also reported that FH-Lalazar is most susceptible to whiteflies and who also found infestation of whiteflies on FH-142 on second number as compared to other genotypes of cotton. The results about thrips population on tested $\mathrm{Bt}$ cotton varieties exposed that maximum resistance against thrips was observed by cotton variety SS-32, which showed per leaf minimum number of thrips (8.57) followed by CRIS-510 (8.81), CRIS-533 (8.87). While per leaf the maximum number of thrips were observed on FH-Lalazar (15.31) followed by FH-142 (10.27) and Bt-CRIS-508 (9.50). These current results are in similarity with [27] who found maximum infestation of thrips on FH-Lalazar, while in analogy with [26] who found minimum number of thrips on FH-Lalazar and FH-142 and also in analogy with [28] who found minimum number of thrips on FH-142 variety of Bt cotton. The results about mealybug infestation on six tested varieties of $\mathrm{Bt}$ cotton revealed that two varieties Bt-CRIS-508 and CRIS-510 showed maximum resistance against mealybug (0.42), (0.43) respectively; followed by FH-142, SS-32, CRIS-533 and FH-Lalazar showed mean population of mealybug (1.49), (1.88), (1.98) and (2.02) respectively. Among all these tested varieties FH-Lalazar was found less resistive to mealybug as compared with other varieties. Our results are in analogy with [30] who described the non-resistivity of $\mathrm{Bt}$ cotton against sucking complex i-e., jassids, whiteflies, thrips, aphids and mealybugs, who also said that pesticides were used to control them.

The overall resistance level of six Bt cotton varieties against different sucking pests was observed, in which cotton variety SS-32 showed better resistance to overall sucking pests (4.60) mean population per leaf followed by CRIS-533 (4.74) and CRIS-510 (4.97), while varieties Bt-CRIS-508 and FH-142 showed moderate resistance to all sucking pests (5.21) and (6.23) mean population per leaf respectively; however, variety FH-Lalazar had not shown enough resistance (8.11) against all the four mentioned sucking pests, so it was considered as most susceptible Bt variety among the tested transgenic varieties. Our results are supported by [31] who reported that there was no significant difference between $\mathrm{Bt}$ and non-Bt cotton varieties in having population of jassid, whitefly and thrips, further also supported by $[32,33]$ who described that $\mathrm{Bt}$ cotton has no effect on population of non-target sucking complex so there is need of regular integrated pest management practices.

The results of population fluctuation of all the four sucking complex on six transgenic cotton varieties illustrated that infestation of the jassid remained above economic threshold level (ETL) almost throughout experimental period except for $1^{\text {st }}$ week of data collection and its peak population was found during $3^{\text {rd }}$ week of August which is (3.94) per leaf. Our findings are in similarity with $[28,31,34]$ who also found peak point of jassid population in the month of august but with little difference between $1^{\text {st }}$ and $3^{\text {rd }}$ week. While the attack of whitefly remained below ETL in starting; during the first three weeks of July then gradually increased and crossed the ETL during the August and its population even more increased in September reached at peak (13.46) per leaf during $2^{\text {nd }}$ week of September. Our findings are in difference with $[4,28,31]$ who described that the whitefly population reached its peak in month of August. Likewise mean population of thrips on various $\mathrm{Bt}$ cotton varieties remained below ETL in July then its population crossed the ETL and reached at peak (17.49) per leaf in the last week of august then its population declined slowly but remained above ETL. Our findings are in similarity with $[4,31]$ they also described that thrips population reached a peak in month of 
August, further support in similar types of results by [35-37]. Our results are different from [28] who found that thrips population was started to gradually build up from last week of June and reached on peak in $1^{\text {st }}$ week of August and then started declined. As for as population fluctuation of mealybug on various $\mathrm{Bt}$ cotton varieties is concerned; it did not appear till the $1^{\text {st }}$ week of August on the all tested varieties of cotton crop then its population increased day by day from the $2^{\text {nd }}$ week of August till the end of September. Our results are in similarity with [38] who described that sucking pest mealybug has emerged on cotton crop after 2 months of cultivation and its population was found till the harvest of the crop.

\section{Conclusion}

Sucking complex, jassid, whitefly, thrips, and mealybug are more dangerous to the cotton crop. Their population was checked on six $\mathrm{Bt}$ cotton varieties under field conditions among them cotton variety FH-Lalazar was found to be more susceptible and cotton variety SS-32 gave the good resistivity against sucking pests. So the variety SS-32 should be cultivated for better production of cotton.

\section{Authors' contributions}

Conceived and designed the experiments: HA Sahito, Performed the experiments: $\mathrm{ZH}$ Shah, Analyzed the data: ZH Shah, Contributed materials/ analysis/ tools: HA Sahito, Wrote the paper: ZH Shah.

\section{References}

1. Pakistan Central Cotton Committee. (2018). Cotistics: Annual Cotton Statistical Bulletin. Ministry of National Food Security and Research. Government of Pakistan. http://www.pcc.gov.pk/pdf\%20files/Coti stics\%202018.pdf.

2. Pakistan Economic Survey. (2015). Agricultural Statistics of Pakistan, Govt. of Pakistan. Min. Food Agric. and Livestock, Eco. Wing, Finance Div., Islamabad, Pakistan http://www.finance.gov.pk/survey/chapter s_15/02_Agricultre.pdf.
3. Gupta MP, Sharma S \& Shrivastava SK (1997). Population build-up of some sapsucking insects on cotton in Madhya Pradesh. J of Insec Sci 10(2): 153-156.

4. Inee-Gogoi B, Dutta C \& Gogoi I (2000). Seasonal abundance of cotton jassid, Amrasca biguttula biguttula (Ishida.) on okra. J of Agri Sci 13: 22-26.

5. Bhatti IM \& Soomro AH (1996). Agricultural inputs. publ directorate general, ars, Hyd, pp 235-338.

6. Ahmad M, Arif MI, Ahmad Z \& Denholm I (2002). Cotton whitefly (Bemisia tabaci) resistance to organophosphate and pyrethroid insecticides in Pakistan. Pest Manag Sci 58: 203-208.

7. Nelson MR, Nadeem A, Ahmad W \& Orum TV (1998). Global assessment of cotton viral diseases. pp. 161-162. In Proc. Beltwide Cotton Conf., San Diego, CA.

8. Oliveira MRV, Henneberry TJ \& Anderson P (2001). History, current status, and collaborative research projects for Bemisia tabaci. Crop Protec 20: 709-723.

9. Shah ZH, Sahito HA, Shar GA, Kousar T, Mangrio WM \& Kanhar KA (2016). Toxicity of different insecticides against mealybug, Phenacoccus solenopsis (Tinsley) under cotton field conditions. Pak J Entomol 31(1): 39-50.

10. Miller DR \& Williams DJ (1997). A new species of mealybug in the genus Pseudococcus Pseudococcidae) of quarantine importance. Proceed of the Entomol Soci of Washington 99: 305-311.

11. Arif MI, Rafiq M \& Ghaffar A (2009). Host plants of cotton mealybug (Phenacoccus solenopsis): a new menace to cotton agroecosystem of Punjab. Int $J$ Agric Biol 11: 163-167.

12. Sahito HA, Abro GH, Mahmood R \& Malik AQ (2011). Survey of mealybug, Phenacoccus solenopsis (Tinsley) and effect of Bio-ecological factors on its population in different ecological zones of Sindh. Pak J Agri, Agri Engg Vet Sci 27(1): 51-65. 
13. Arif MJ, Gogi MD, Mirza M, Zia K \& Hafeez F (2006). Impact of plant spacing and abiotic factors on population dynamics of sucking insect pests of cotton. Pak J of Bio Sci 9: 1364-1369.

14. Khan MA, Khaliq A, Subhani MN \& Saleem MW (2008). Incidence and development of Thrips tabaci and Tetranychus urticae on field-grown cotton. Inter J of Agri Biol 10: 232-234.

15. Bashir MH, Afzal M, Sabri MA \& Raza AM (2001). Relationship between sucking insect pests and physio-morphic plant characters towards resistance/susceptibility in some new cotton genotypes of cotton. Pak Entomol 23: 75-78.

16. Raza AM \& Afzal M (2000). Physiomorphic plant characters in relation to resistance against sucking insect pests in some new cotton genotypes. Pak Entomol 22: 73-78.

17. Kranthi KR \& Kranthi NR (2004). Modeling adaptability of the cotton bollworm, Helicoverpa armigera (Hubner) to Bt., cotton in India. Current Sci 87: 1096-1107.

18. Bughio AR, Rahman A, Zafar AQ, Hussain T, \& Siddiqui QH (1984). Field evaluation of cotton mutants for pink and spotted bollworms resistance. The Nucl Pak 21: 47-49.

19. Jin ZQ, Cao GD, Luo SS, Hong JM\& Hung YQ (1999). Insect resistance and yield of different insect-resistant hybrid cotton cultivars. Zhejiang Nongye Kexue, 3: $142-144$.

20. Khan MT, Naeem M \& Akram M (2003). Studies on the varietal resistance of cotton against insect pest complex of cotton. Sarhad J Agri 19: 93-96.

21. Krips OE, Kleijn PW, Willems PEL, Gols GJZ \& Dicke M (1999). Leaf hairs influence searching efficiency and predation rate of the predatory mite Phytoseiulus persimilis (Acari; Phytoseiidae). Exp Appl Acarol 23: 119131.
22. Afzal M \& Bashir MH (2007). Influence of certain leaf characters of some summer vegetables with incidence of predatory mites of the family Cunaxidae. Pak J Bot 39: 205-209.

23. Hassan M, Ahmad F \& Waheed W (2000). Role of biochemical components in varietal resistance of cotton against sucking insect pests. Pak Entomol 22: 6972.

24. Shad SA, Akram W \& Abrar R (2001). Relative susceptibility of different cultivars of cotton to sucking insect pests at Faisalabad. Pak Entomol 23: 79-81.

25. Aslam MM, Razaq NA, Saeed \& Ahmad F (2004). Comparative resistance of different cotton varieties against bollworm complex. Int J Agric and Biol 6: 39-41.

26. Akhtar ZR, Irshad U, Majid M, Saeed Z, Khan H, Anjum AA, Noreen A, Salman MA \& Khalid J (2018). Risk assessment of transgenic cotton against non-target whiteflies, thrips, jassids and aphids under field conditions in Pakistan. $J$ of Entmol and Zool St 6(2): 93-96.

27. Nazir MS, Malik TA, Shakeel A \& Ahmad JN (2019). Potential resistance of Okra leaf Bt., cotton against insect pests. Appl Ecol and Environ Res 17(3): 5465-5469.

28. Saleem MJ, Hafeez F, Arshad M, Atta B, Maan NA, Ayub MA \& Zubair M (2018). Population Dynamics of Sucking Pests on Transgenic Bt., Cotton in Relation with Abiotic Factors and PhysioMorphological Plant Characters. $J$ of Entomol and Zool St 6(6): 163-166.

29. Singh J, Gill RS, Brar APS \& Sandhu BS (1996). Evaluation of some exotic cotton hybrids against insect pests", Crop Impr 23(2): 275-277.

30. Arshad M, Khan RR, Aslam A \& Akbar W (2018). Transgenic Bt Cotton: Effects on Target and Non-Target Insect Diversity. Past, Pres and Futur Trends in Cotton Breed, pp155.

31. Arshad M \& Suhail A (2010). Studying the sucking insect pests community in 
transgenic Bt., cotton. Int J of Agric and Biol 12: 764-768.

32. Men XY, Ge F, Liu XH \& Yardim EN (2003). Diversity of arthropod communities in transgenic Bt., cotton and non-transgenic cotton agro-ecosystems. Environ Entomol 32: 270-275.

33. Bambawale OM, Singh A, Sharma OP, Bhosle BB, Lavekar RC \& Dhandapani A (2004). Performance of Bt., cotton (MECH-162) under integrated pest management in farmers' participatory field trial in Nanded district, Central India. Current Sci 86: 1628-1633.

34. Ashfaq M, Noor-ul-Ane M, Zia K, Nasreen A \& Mansoor-ul-Hasan (2010). The correlation of abiotic factors and physico-morphic characteristics of $\mathrm{Bt}$ (Bacillus thuringiensis) transgenic cotton with whitefly, Bemisia tabaci (Homoptera: Aleyrodidae) and jassid,
Amrasca devastans (Homoptera: Jassidae) populations. Africa J Agric Res 5(22): 3103-3107.

35. Abro GH, Syed TS, Tunio GM \& Khuhro MA (2004). Performance of transgenic Bt., cotton against insect pest infestation. Biotechnol 3: 75-81.

36. Solangi GS, Mahar GM \& Oad FC (2008). Presence and absence of different insect predators against sucking insect pest of cotton. J Entomol 5(1): 31-37.

37. Godhani PH, Patel RM, Jani JJ, Yadav DN, Korat DM \& Patel BH (2009). Impact of habitat manipulation on insect pests and their natural enemies in hybrid cotton. Karnataka J Agric Sci 22(1): 104-107.

38. Sahito HA, Abro GH, Khuhro RD \& Buriro AS (2009). Varietal resistance of cotton crop against mealybug, Phenacoccus solenopsis Tinsley. Pak J of Agri, Eng Veter Sci 25 (1): 34-38. 